Franklin Bialystok

\title{
What Was Known? What Was Reported? What Was Done? What Could Have Been Done?
}


It is appropriate, thirty-six years after the publication of None Is Too Many, to reconsider 1944 from the perspective of Canadian Jewry. As Canadians, they were swept up in the war effort, at home and in combat. As Jews, they were frantic about the destruction of Jewish life. In consideration of the questions raised in the title of this paper, we present, somewhat in contrast to Abella and Troper, the following assessment. First, the organized Jewish community, in the context of Canadian ethno-cultural minorities, had a voice. Second that information about the Holocaust, while often inaccurate, was widely published, especially in the Yiddish press. Third, that despite Canada's complete abdication of political will in providing opportunities for Jews to flee Europe and find a refuge in Canada, the reality of the war, the absence of historical precedent, and the impossibility of foreseeing the calamity, ensured that a comprehensive plan of meaningful rescue could not have been attempted, let alone considered.

Il est approprié, trente-quatre ans après la publication de None Is Too Many, de reconsidérer l'année 1944 du point de vue de la communauté juive canadienne. En tant que Canadiens, ils ont été emportés dans l'effort de guerre, à la maison et au front. En tant que Juifs, ils ont été terrifiés par la destruction de la vie juive européenne. En considération des questions soulevées dans le titre de cet article, nous présentons une évaluation qui nuance celle d'Abella et de Troper. Premièrement, la communauté juive organisée, dans le contexte des minorités ethnoculturelles canadiennes, a eu une voix. Deuxièmement, les informations sur l'Holocauste, bien que souvent inexactes, ont été largement publiées, en particulier dans la presse yiddish. Troisièmement, malgré l'abdication totale de la volonté politique du Canada de donner la possibilité aux Juifs de fuir l'Europe et de trouver refuge au Canada, la réalité de la guerre, l'absence de précédent historique, et l'impossibilité de prévoir la calamité ont assuré qu'un plan complet de sauvetage significatif n'aurait pas puêtre considéré, encore moins tenté.

The year 1944 was calamitous in the equilibrium of global events. It marked both the denouement of Axis control of Europe and Eastern Asia and the penultimate stage of the Holocaust. In Canada, the country was riven by the Conscription Crisis, fixated on the war effort at home and abroad, and apprehensive about the prospect for a rapid victory in light of the Allied invasion of Europe. For Canadian Jewry, their apprehension was multiplied by the fate of their European brothers and sisters. They received irregular and often inaccurate information about the genocide, and their community leaders were stonewalled in their entreaties to the King government to alleviate the crisis of Jewish refugees by withdrawing the restrictions to emigrate.

Our understanding of the tenor of Canadian Jewry in 1944 is largely due to Irving Abella and Harold Troper's None Is Too Many: Canada and the Jews of Europe, published in 1982. Indeed, the title has become a catch phrase to rally Canadians to 
open the country's door to refugees, from the Vietnamese boat people at the time of the publication of the author's initial research ${ }^{\mathrm{I}}$ to the recent adoption of Syrian exiles. Nevertheless, a reconsideration of 1944 , in light of the voluminous research on the Holocaust and on Canadian Jewry since i982, complicates these authors' perspectives.

We raise four questions regarding the plight of European Jewry and the response by Canada's Jews and by Canadians: What was known? What was reported? What was done? What could have been done? The first two questions are not congruent. What was reported to Canadian officials via London and Washington was not necessarily believed. What was reported to Canadians was not necessarily accurate. The greater complication, however, was the enormous gap between the knowledge that European Jewry was being decimated, and the comprehension of what that entailed, a gap that took some thirty years to resolve. The third question is viewed from two perspectives - the Canadian government and the Jewish community. There is no deviation from Abella and Troper's assertion that there was no intent or effort by the authorities to offer a haven to European Jewry, and that Canadian Jews took up the mantle to save their brethren. Nevertheless, we question Abella and Troper's contention that the Jewish community "had no leverage." ${ }^{2}$ But that conversation doesn't consider the fourth question - that even had there been political will, only a miniscule fraction of the intended victims could have been rescued.

Consequently, we offer three points. First, the Canadian Jewish community in 1944 was unrivalled in its organization and its access to political leaders in comparison to other ethno-cultural minorities. Second, while information about the genocide tended to be inaccurate and in some respects withheld from Canadians, the broad strokes of the destruction of European Jewry was well known, especially via the Yiddish language press. Finally, while there was no Canadian response to the genocide, any hope of saving even a remnant of European Jewry was negligible, given the context of the war and the absence of historical precedent for such action. Aside from the gaps between information and belief, and between knowledge and comprehension, it would have taken a prophet to foresee the enormity of the Holocaust.

We open with an overview of Canada's Jews, Canadian society, and the war in Europe, in 1944. There were approximately 170,000 Jews in Canada, representing about I.5 percent of the populace. Some 85 percent lived in Montreal, Toronto, and Winnipeg, but several hundred communities had at least one Jewish resident. Due to the increasingly stringent immigration restrictions in the interwar period, a slight majority was born in Canada. The community had a wide array of organizations to which members belonged, from synagogues, landsmanshaften, local federations, political/social/labour/Zionist groups, B'nai Brith, and the Canadian Jewish Congress (CJC). CJC was reborn in 1934 and by the start of the war had become the most important voice in the community and arguably the strongest ethno-cultural 
advocacy organization in the country. By 1939, when it was headed by Samuel Bronfman who provided financial support and his prominent voice, it had some measure of impact on the national agenda. Together with B'nai Brith, CJC formed the Joint Community Relations Committee in 1938 and became an influential agency for human rights.

Anti-Semitism had effloresced in the interwar period; that restricted access to education, housing, accessibility to public spaces, and - most significantly - to employment. Traditional religious anti-Semitism was most felt by Quebec's Jews and was accelerated within the growing nationalist movement. In the West, nativist movements were on the rise and had gained ascendancy in Alberta. Across the country, neo-fascists supported Germany and Italy, especially with regard to their condemnation of Jews. ${ }^{3}$ Yet, one must understand the context of anti-Semitism within the broad scope of attitudes and practices inflicted on other minorities. Japanese Canadians were dispossessed and incarcerated. South and East Asian immigration had long been suppressed, and First Nations were victims of cultural genocide. ${ }^{4}$ Negative attitudes toward Canada's Jews were also expressed about other ethnic Europeans, but Jews were in the process of adapting and acculturating themselves to Canadian life more rapidly than these groups. One indication of this adjustment was that 16,000 Jewish men and women served in the Armed Forces, a ratio just under the national average. In part, enlistment was spurred by CJC's formation of the War Effort Committee of CJC. ${ }^{5}$

In examining the history of the Holocaust in 1944, we see that the knowledge of what was taking place tended to be inaccurate or disregarded. By the fall of 1943, Germany was in retreat in the Soviet Union, and the Allies had gained a foothold in southern Italy and repelled the Axis powers in North Africa. Through the first half of 1944, German forces had retreated to central prewar Poland, and were fighting the Allied invasion in France. By the end of the year, Germany was facing a pincer movement, and Italy had fallen.

With regard to the plight of the Jews, by the fall of 1943 , the only remaining major ghetto was Lodz, and the only remaining "extermination" (to use the German term) facility was the Auschwitz/Birkenau complex. The other sites, Treblinka, Belzec, and Sobibor, had been razed. The final transports from Western Europe occurred through the spring of 1944. The only unaffected Jewish community was in Hungary, but with the German takeover, in short order some 500,000-565,000 Jews were killed, representing 87 percent of the community. The Lodz ghetto was liquidated at the end of August, and Auschwitz was abandoned in January 1945. The final stage of the Holocaust was the death marches into prewar Germany, where most of the last fragment of the victims met their end. ${ }^{6}$ 
The major obstacles to providing information about the Holocaust ranged from geography (the occurrences in Central and Eastern Europe) to the context of the war (no western Allied forces in trans-Alpine Europe until D-Day), relegating the plight of the Jews far behind the determination to defeat Germany, disbelief, and antiSemitism. Canada's Ministry of External Affairs received information via London, so that it knew of Jews trapped in Vichy France in 194I, of the deportations from the Warsaw Ghetto in 1942, of mass murder in the Soviet Union and Lithuania in 1942, and of accounts of the destruction of Hungarian Jewry in the summer of 1944. However, some of these reports were either outdated or inaccurate. For example, in May 1944, one report stated that "there were 300,000 Polish Jews alive, as many or more in the USSR," and it also spoke of the "deportation of Hungarian Jews to Auschwitz and Treblinka" in 1944, even though Treblinka was gradually shut down after August 1943.

In addition, eyewitness accounts were discounted. Two examples are cited. Jan Karski, a courier for the Polish government in exile, smuggled himself into Poland and saw the deportations from the Warsaw Ghetto to Treblinka; he also learned of the gassing at Chelmno and of the mass murder in conjunction with the invasion of the Soviet Union. His reports in London were scoffed at by British officials, and similarly by American leaders when Karski went to Washington. ${ }^{7}$ The murder of Hungarian Jews was witnessed and recorded by Rudolf Vrba and Alfred Wetzler, Auschwitz inmates who escaped. Their report, dubbed the Auschwitz Protocols, reached the World Jewish Congress in Switzerland. Even so, they were disregarded by the Allied Command. Nevertheless, the Jewish Labour Committee published them, and they were disseminated to independent journalists. ${ }^{8}$

What did Canadians know about the Holocaust? For readers of the Toronto Star, the reports by Pierre Von Paassen told of the hardships of Polish Jews from the German invasion through the war. He beseeched the King administration to provide a haven, a lone cry in the wilderness. But the paper's coverage was not consistent, and it was entirely absent in I94I and 1942. Liberty Magazine reported in November 1943 of the mass murder in Babi Yar which had occurred two years earlier, and it reported on Treblinka, Belzec, and Sobibor, which had already been destroyed. Although Canadian leaders had authenticated accounts of systematic mass murder during the summer of 1943, they were not made public. Similarly, although CJC had reports of the gas chamber complexes in 1942 - shortly after they were erected - and reports of the May 1943 liquidation of the Warsaw Ghetto in September 1943, it chose to keep them under wraps, perhaps because of fear of inflaming anti-Jewish reactions, because they would not (or could not) be authenticated and/or believed. ${ }^{9}$

What did Canadian Jews know? To begin, it depended upon whether they read the Jewish press in English or in Yiddish. While the Canadian Jewish Chronicle (which 
shared its office with the Keneder Adler) published reports well in advance of the English press, Winnipeg's Jewish Post did so in less depth, and the Canadian Jewish Review was virtually silent, perhaps of fear of anti-Jewish reprisals. The Yiddish press, however, was not bound by such consideration as it provided regular reports, often from non-governmental sources, including the Karski investigations.

Even so, information in the Yiddish press was occasionally distorted. This was most notable in the reports by Raymond Davies to the Adler from Lublin (which had fallen to the Red Army) in October 1944. He wrote that in the nearby Majdanek camp, approximately one million Jews and half a million others were killed. In fact, the total was approximately 200,000 victims, two-thirds of whom were Jewish..$^{10}$ He told of the liberation of Belzec, Sobibor, and Treblinka. These camps were not liberated. German troops destroyed them a year or more earlier, in part to cover the evidence of the atrocities. There were few "eyewitnesses" as there were a handful of escapees from Treblinka, and almost none from the other two. Nevertheless, as Rebecca Margolis argues in this volume, "the destruction of European Jewry under the Nazis was the story in all facets of the country's three major Yiddish newspapers." remains that those who wanted to know could know, even if the reportage was not necessarily up to the minute or completely accurate.

But what did they comprehend? Separated by time and space from their lands of origin, it was difficult to appreciate that a millennial Jewish civilization had been destroyed. In fact, in the spring of 1944, when some five million had already been murdered, reports of gas chambers in Auschwitz were incomprehensible not only to the world, but those about to be ensnared. One telling example was the refusal of the Jews of Sighet (on the Hungarian/Romanian frontier), at the height of the transports, to believe what was happening - as depicted by Elie Wiesel. ${ }^{12}$ Many survivors maintain that even they could not comprehend the calamity. In studies of Canadian survivors, this theme was not a marginal one. If "comprehension" was ephemeral among some of the 30,000 survivors who migrated to Canada between I947 and 1956, it was more pronounced for many Jews born or raised in Canada. This was a factor in the chasm of understanding between the two groups, one that only came to be ameliorated to a degree some thirty years after the war. For some, that gap never narrowed. ${ }^{13}$

How did Canadian Jews respond? The short answer is that they responded with vigour and determination. In its reorganization in 1934, the Canadian Jewish Congress was hampered by competition between its Montreal and Toronto factions, lessening the effectiveness of its advocacy. This changed with Samuel Bronfman's accession as president and the appointment of Saul Hayes as its director. CJC became focused on the main concern and proceeded to directly lobby Mackenzie King. By 1944, it pleaded with the government to participate in a British scheme to rescue Hungarian 
children, to no avail. Troper and Abella maintained that the Jewish leadership was powerless, a view that I supported in 2000 , calling it "timorous."

As I began actively studying, teaching, and writing Canadian Jewish history after the publication of Delayed Impact under the supervision of Irving Abella, I revised my position. I looked at the context of Canadian attitudes towards all non-AngloCeltic/Northern European immigrants. The "one wailing cry" was not confined to Canadian Jews. I further looked at the pressure in a variety forms by Canadian Jews, from the CJC to individuals, and with respect to the former, to the access to King and his acolytes. This is astonishing relative to the absence of any influence on government policies by Canada's most aggrieved minorities. What other ethnocultural minority had a direct pipeline to Ottawa? Or had three Jewish Members of Parliament? It wasn't a lack of Jewish advocacy that prevented King from responding to the crisis. Meanwhile, the pressure wasn't exercised by Bronfman and Hayes alone. The Federation of Polish Jews, numerous landsmanschaften, the Jewish Labour Committee, the Jewish Immigrant Aid Society, and certainly the Yiddish language press were vociferous in their appeals and ultimately in their condemnation of the government's refusal to respond. ${ }^{\text {I4 }}$

What was done? Very little. Abella and Troper maintain that only 5,000 Jews were allowed to enter Canada between 1933 and 1945. In a recent article, Justin Comartin looks at Louis Rosenberg's research, rather than the internal correspondence of the Immigration Branch, upon which Abella and Troper relied for their figure. ${ }^{15}$ Comartin concludes that the number of arrivals was 8,787 . While this hardly counts as an inspiring response to the crisis, it indicates that Canada's record was marginally less appalling.

But asking what was done masks the far greater and complex question of what could have been done. The main barrier is that we read history backwards. As such, we expect that Canada "in the free and civilized world," to borrow Abella and Troper's phrase ${ }^{16}$ should have foreseen the destruction of European Jewry. If so, how? Where was the precedent? Historians of the Holocaust have debated whether the Nazi Party intended the murder of the Jews of Europe all along or ended up doing so as a function of internal competition between the Party, the bureaucracy, the armed forces, and the industrialists. Even so, it wasn't until the summer or fall of 194I (depending on the historian) that the decision to annihilate was taken. This could not have been foreseen in 1933, at Kristallnacht, or at the invasion of Poland, nor could it have even been comprehensible when the decision was enacted.

A second limiting factor for rescue comes back to what was known and what was comprehended. To which we add, what was possible. By the summer of I94I, by what means could the masses of Jews - or even tens of thousands of them - have 
been saved? Germany and its allies and accomplices had control of Europe from the Atlantic to the Russian steppes. By what means could rescue have taken place? Hence, our concentration is limited to those trapped in Vichy, who could possibly smuggle themselves to Iberia. ${ }^{17}$ The third factor is the lack of precedent. When had nations banded together to save a nation that was being annihilated? Further, when had an entire nation/people/religion been designated for annihilation $?^{18}$ Fifty years after the end of the war - in a world of instant communication, of a United Nations - one nation, the Tutsis, were almost wiped out in the span of ten weeks using primitive weapons. There was a precedent in 1994 - the Holocaust - and there was a means political will in the Western world. But neither the precedent nor the means were acted upon.

Nevertheless, it is important to separate the limiting factors for rescue from the openly anti-Jewish sentiments of the Canadian authorities and much of Canadian society as a whole. One need only look at the refusal to admit survivors to Canada until there was pressure from industrialists for workers to meet the demands of the postwar economy. Even so, it wasn't until 1950 that the barriers to entry for the survivors were fully withdrawn.

The year 1944 was a turning point in history. European Jewry had vanished. Canadian Jews tried mightily to mitigate the slaughter, even though reports were inaccurate and more prolific only in the Yiddish-language press. Canadian society was totally focused on the Depression and the war, and it was historically hostile to non-Anglo immigrants and their descendants, and to its First Nations. Its leadership saw no political advantage in helping save even a fragment of European Jewry. Even had there been the political will to engage in rescue, Axis control from the Atlantic to the Russian steppes, the absence of precedent, and the impossibility of reading history forward all conspired to dash a meaningful rescue. Although Canadian Jews only came to appreciate the magnitude of the Holocaust decades after the cataclysm, their efforts to support their brethren were laudable, and they continue to be documented by this generation of scholars. 
1

Irving Abella and Harold Troper, "The Line Must Be Drawn Somewhere: Canada and Jewish Refugees 1933-9," Canadian Historical Review 60, no.2 (1979): 178-209.

\section{2}

Irving Abella and Harold Troper, None Is Too

Many: Canada and the Jews of Europe, 1933-

1948 (Toronto: Lester and Orpen Dennys, 1982), 283.

\section{3}

The output of literature on the topic is commendable. A sample, in chronological order, includes: Lisa-Rose Betcherman, The Swastika and the Maple Leaf: Fascist Movements in Canada in the Thirties, (Toronto: Fitzhenry and Whiteside, 1975). Alan Davies, ed., Antisemitism in Canada: History and Interpretation, (Waterloo: Wilfred Laurier University Press, 1992). Janine Stingl, Social Discredit: Antisemitism, Social Credit, and the Jewish Response (Montreal and Kingston: McGill-Queen's University Press, 2000). Richard Menkis, "Anti-Semitism from New France to 1950," in R. Klein and F. Dimant, eds., From Immigration to Integration: The Canadian Jewish Experience (Toronto: Malcolm Lester, 2001). Morton Weinfeld, "The Changing Dimensions of Contemporary Canadian Anti-Semitism," in D. Penslar, M. Marrus, and J. Gross Stein, eds., Contemporary Antisemitism: Canada and the World (Toronto: University of Toronto Press, 2005). Ruth Klein, ed., Nazi Germany, Canadian Response: Confronting AntiSemitism in the Shadow of War (Montreal and Kingston: McGill-Queen's University Press, 2012). Ira Robinson, A History of AntiSemitism in Canada (Waterloo: Wilfred Laurier University Press, 2015).

\section{4}

The breakthrough studies appeared in the wake of None Is Too Many, which was one catalyst for this research. See: Angus McLaren, Our Own Master Race: Eugenics in Canada, 1885-1945 (Toronto: McClelland and Stewart, 1990). Ormond McKague, ed., Racism in Canada (Saskatoon: Fifth House, 1991). N. Hillmer, B. Kordan, L. Luciuk,eds., On Guard For Thee: War, Ethnicity and the Canadian State, 1939-1945 (Ottawa: Canadian Government Publishing Centre, 1988). Robin W. Winks, The Blacks in Canada: A History ( $2^{\text {nd }}$ edition) (Montreal and Kingston : McGillQueen's University Press, 1997).
5

Gerald Tulchinsky "Jews at War," in Branching Out: The Transformation of the Canadian Jewish Community (Toronto: Stoddart, 1998).

6

A thorough survey is Israel Gutman, ed., Encyclopedia of the Holocaust four volumes (London: MacMillan, 1990).

\section{7} See "Karski" in Gutman, ed., Encyclopedia of the Holocaust, 1990. One resource in the growing literature on Karski is $\mathrm{E}$. Thomas Wood and Stanislaw M. Jankowski, Karski: How One Man Tried to Stop the Holocaust (London: Wiley, 1994).

\section{8}

Auschwitz Protocols, in Guttman (ed.), Encyclopedia of the Holocaust, Volume One, 121-2.

\section{9}

Ulrich Frisse, "The Bystanders Perspective: The Toronto Daily Star and its coverage of the Jews in the Holocaust in Canada," in Yad Vashem Studies 39, vol.1 (2000): 213-43. David Goutor, "The Canadian Media and the 'Discovery' of the Holocaust, 1944-1945," Canadian Jewish Studies IV-V (1996-1997): 86-115. Rebecca Margolis, "A Review of the Yiddish Media: Responses of the Jewish Immigrant Community of Canada," and Amanda Grzyb, "From Kristallnacht to the MS St. Louis Tragedy: Canadian Press Coverage on Nazi Persecution of the Jews and the Jewish Refugee Crisis, September, 1938 to August 1939," in Ruth Klein, ed., Nazi Germany, Canadian Responses, 78-143.

10

See Doris Bergen, War and Genocide: A Concise History of the Holocaust (Lanham, MD: Rowman and Littlefield, 2003). The number of victims at Majdanek main camp and subcamps ranges according to the source. According to The United States Holocaust Memorial Museum, there were $80,000-110,000$ victims in the main camp and $95,000-130,000$ victims in the subcamps.

11

Rebecca Margolis, "The Keneder Adler and Yiddish community life in Montreal, 1944" Canadian Jewish Studies XXVII (2018). 
12

Elie Wiesel Night (New York: Bantam Books, 1982), 1-5.

\section{3}

See Franklin Bialystok, Delayed Impact: The Holocaust and the Canadian Jewish Community (Montreal and Kingston McGillQueen's University Press, 2000); Adara Goldberg, Holocaust Survivors in Canada: Exclusion, Inclusion, Transformation, 1947-1955 (Winnipeg: University of Manitoba Press, 2015). Beyond fictional accounts by Holocaust survivors, there is a body of memoirs by Canadian Holocaust survivors, in large part due to the efforts of the Azrieli Foundation: http://memoirs. azrielifoundation.org/survivor . In them, the "incomprehension" theme is a consistent trope.

\section{4}

Max Beer, What Could Have Been Done? The Montreal Jewish Community, the Canadian Jewish Congress, the Jewish Press, and the Holocaust, MA thesis, Concordia University, 2006.

\section{5}

Justin Comartin, “Opening Closed Doors: Revisiting the Canadian Immigration Record (1933-1945)," Canadian Jewish Studies XXIV (2016): 77-102. In the same volume, see Norman Erwin, "The Holocaust, Canadian Jews, and Canada's 'Good War" Against Nazism," 103-124. For the Jewish Labour Committee, see Bialystok, Delayed Impact, 2627 and 50-56, and James Walker, "Claiming Equality for Canadian Jews: The Struggle for Inclusion, 1930-1945," in Klein, ed., Nazi Germany, Canadian Responses, 218-260.

\section{6}

Abella and Troper, None Is Too Many, 148.

\section{7}

For a recent opinion, see "Historians reject claim Allies could have saved Jews," Canadian Jewish News, 4 May 2017, 27.

\section{8}

The caveats are the destruction of the Herero by Germany and the Armenians by the Turks, although in the first case it was a feature of colonial conquest, and in the second case it occurred within the boundaries of the emerging Turkish state. Both cases are distinct from the Holocaust for several reasons, one being that Germany imposed its policy on conquered and allied lands as well as its own territory. See Horst Drechler, "The Herero Uprising," and Richard G. Hovannisian, "The Historical Dimensions of the Armenian Question, 1878-1923," in The History and Sociology of Genocide: Analyses and Case Studies, Frank Chalk and Kurt Jonassohn, eds. (New Haven and London: Yale University Press, 1990), 231-265. For bibliographies, see the following within the index of Chalk and Jonassohn: Armenians in Turkey, pp. 433-4; Hereros, p. 438. 